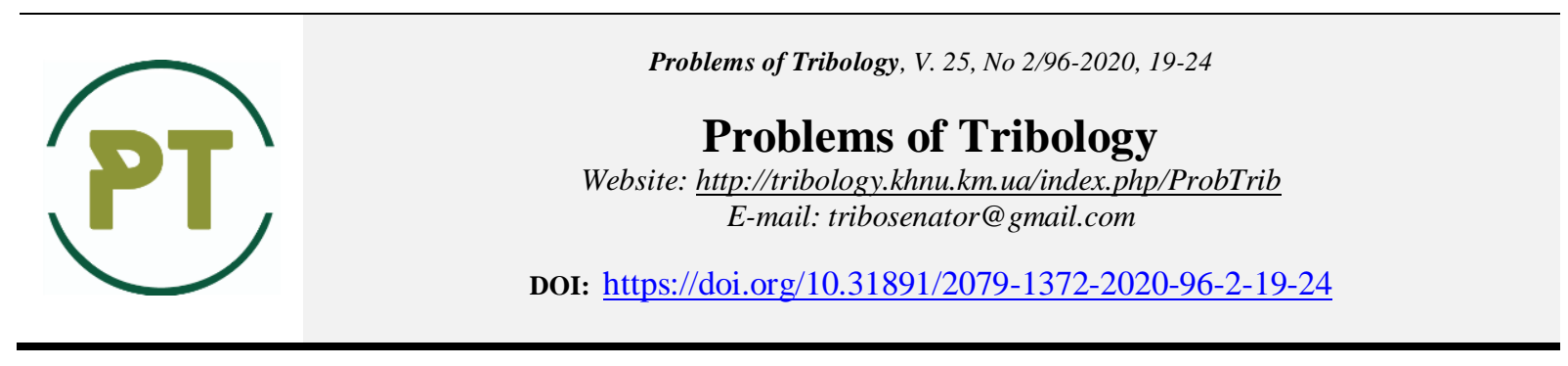

\title{
Adsorptive regeneration of used industrial oils
}

\author{
O. Khudoyarova ${ }^{1}$, O. Gordienko ${ }^{2}$, T. Titov ${ }^{2 *}$, A. Ranskiy ${ }^{2}$, A. Dykha ${ }^{3}$ \\ ${ }^{l}$ Vinnytsia Mykhailo Kotsiubynsky State Pedagogical University, Ukraine \\ ${ }^{2}$ Vinnytsia National Technical University, Ukraine \\ ${ }^{3}$ Khmelnytsky National University, Ukraine \\ ${ }^{*}$ E-mail: tarastitov88@gmail.com
}

\begin{abstract}
The feasibility of using a pre-regenerated mixture of sorbents consisting of activated charcoal and kieselguhr for the regeneration of used industrial oils has been investigated. The basic physico-chemical properties of regenerated industrial oil have been established, which indicates the efficiency and manufacturability of the purification method and the possibility of its reuse for the intended purpose.

Keywords: used industrial oils, adsorption, activated charcoal, kieselguhr, regeneration

\section{Introduction}

The global experience of industrialized countries testifies to the undeniable energy and economic feasibility of the regeneration of used oil [1-3]. In such countries, the part of regenerated oils (of their total production) is about $30 \%$, and in Germany this value is even higher, reaching $55 \%$. In this case, German law obliges the producer of oils to add at least $10 \%$ of the so-called refining base oil in their production. It should be noted that the production of 1 liter of oil by vacuum distillation requires 1 barrel (159 liters) of crude oil [4]. This indicates that oil production is the most valuable part of oil refining, so that in order to rationally use this important natural resource for Ukraine, used oils should be considered as secondary industrial raw materials. However, according to statistics, about $25 \%$ of used oils in Ukraine are collected from their total use, and only $15 \%$ is recovered, which is about $3 \%$ of total consumption. At the same time, a significant part, for example, of used oils of private vehicles (30-50\%) gets into the environment or sewage, which violates the Decree of the Cabinet of Ministers of Ukraine No. 1221 of 17.12.12, which approved the «Procedure of the collection, removing, neutralization and utilization of used lubricants (oils)».
\end{abstract}

\section{Literature analysis and problem statement}

Today, various physical methods (settling, filtration, centrifugal purification, vacuum distillation) are used for regeneration of used oils, which allows to remove mechanical impurities, water and light hydrocarbons $[3,4]$. Physico-chemical methods (coagulation, adsorption, ion exchange purification, extraction) allow to partially or completely remove acidic or pitch-asphaltene substances [5-10,14]. The use of chemical methods of purification of used oils (sulphate, alkaline or hydrotreating) allows almost completely to clean the oils from pollutants and to bring them as close as possible to the physico-chemical characteristics of pure oils $[1,4,11]$. It should be noted that the choice of method of regeneration of used oils depends on the degree of contamination/destruction of used oils, as well as on the possibilities of their reuse, economic, technological capabilities of the enterprise and a number of other factors. Thus, the most common sequence of used oil regeneration operations is shown in fig. 1, including the removal of impurities - 1; dehydration - 2; extraction of light hydrocarbons - 3; extraction of pitch-asphaltene substances - 4; introduction of alloying additives/compounding - 5 . 


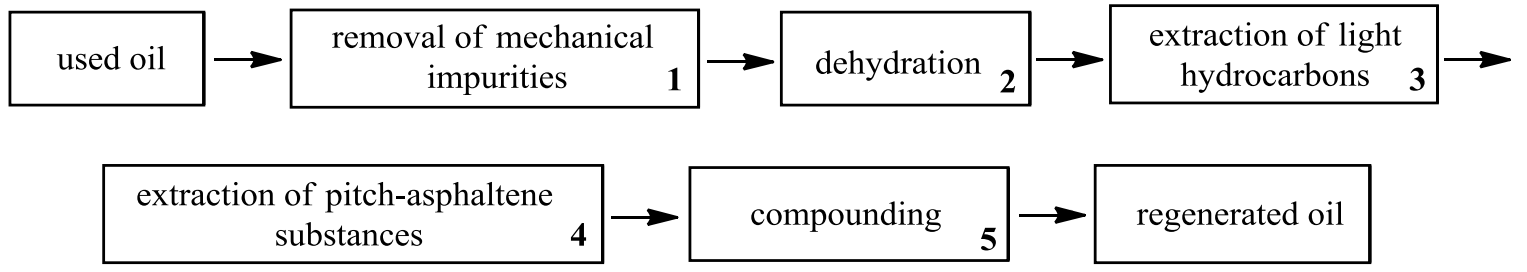

Fig. 1. The sequence of operations for the regeneration of used oils

In most cases, industrial oils operate at relatively low temperatures (no more than $65-70^{\circ} \mathrm{C}$ ) in the absence of direct contact with water vapor, hot air, and aggressive chemical environment. As a rule, these are friction units such as bearings, shafts, pins, bushings of various metal-working machines, textile equipment, devices and hydraulic systems. During operation, they become contaminated with mechanical impurities, water, pitchasphaltene substances of oxidation processes and become unusable for further operation. The method of their purification using synthetic and natural sorbents is effective and technological. It should be noted that the adsorption purification/regeneration of used industrial oils is in many cases technologically expedient, and the presence of a large number of natural sorbents in Ukraine makes this method attractive both economically and commercially.

\section{The goal of the work}

The goal of the work is to study the adsorption method of purification/regeneration of used industrial oils using a regenerated mixed sorbent.

\section{The experimental part}

For the study of adsorption purification/regeneration, the used oil (UO) I-40A of bench hydraulics of the excavator of the educational laboratory of the Department of Technology and Automation of Mechanical Engineering of the Faculty of Mechanical Engineering and Transport of Vinnytsia National Technical University was used.

The adsorption purification of used industrial oils was carried out using a pre-regenerated sorbent mixture of Panda Production Company (Vinnytsia) [12], which consisted of activated charcoal (AC) of the brand Decolar A and kieselguhr (K) of brands Becogur 200 and Becogur 3500 in 4:6 mass ratio, staggered on a INDURA filter press carton.

General method of purification/regeneration of used industrial oil. $10 \mathrm{~g}$ of the mixed sorbent was added to $100 \mathrm{~g}$ of used industrial oil I-40A pre-filtered from mechanical impurities in a mass ratio $(\mathrm{AC}+\mathrm{K}):(\mathrm{UO})=$ 1:10. The mixture was stirred on a high-speed magnetic stirrer $(1000-1200 \mathrm{rpm})$, at $20-25^{\circ} \mathrm{C}$ during 60 minutes. The mixture was then filtered and the basic physico-chemical characteristics were determined for the purified oil.

The kinematic viscosity was determined according to DSTU GOST 33-2003 using glass capillary viscometers of VPG-1 and VPG-2. The number of measurements was not less than 5, and the error difference did not exceed $0.3 \%$.

Water content was determined according to GOST 2477-65 using a laboratory installation, which included a Dean-Stark trap, according to the formula:

$$
W=V \cdot \frac{\rho}{m},
$$

where $W$-water content, $\%$ wt.; $V$ - volume of water in the trap, $\mathrm{ml} ; \rho$ - density of the dispersed phase, $\mathrm{g} / \mathrm{ml} ; \mathrm{m}$ - sample of the determined oil, g.

The acid value was determined according to GOST 5985-79 by direct titration of oil I-40A with alcoholic solution of $\mathrm{KOH}$ in the presence of alkaline blue $6 \mathrm{~B}$ indicator by the formula:

$$
K=\left(V_{1}-V_{2}\right) \cdot \frac{T}{m}
$$

where $\mathrm{V}_{1}$ - volume of $0.05 \mathrm{M}$ alcoholic solution of $\mathrm{KOH}$ spent on sample titration, $\mathrm{ml}$; $\mathrm{V}_{2}-$ volume of $0.05 \mathrm{M}$ alcoholic solution of $\mathrm{KOH}$ spent on the titration of the control sample, $\mathrm{ml}$; $\mathrm{T}$ - titer of $0.05 \mathrm{M}$ alcoholic solution of $\mathrm{KOH}, \mathrm{g} / \mathrm{ml} ; \mathrm{m}$ - sample mass, $\mathrm{g}$

The density was determined according to GOST 3900-85 using pycnometers according to the formula: 


$$
\rho=\frac{\left(m_{1}-m_{2}\right)}{m_{3}},
$$

where $\mathrm{m}_{1}$ - mass of pycnometer with oil I-40A, $\mathrm{g} ; \mathrm{m}_{2}-$ mass of empty pycnometer, $\mathrm{g}$; $\mathrm{m}_{3}$ - water value of the pycnometer, g. The difference between the parallel studies did not exceed 0.0004 .

The optical density was determined according to GOST 24943-81 on the photocolorimeter KFK-3-01 at a wavelength $470 \mathrm{~nm}$. As a result of the analysis, the arithmetic mean of two parallel definitions was accepted, the difference between which differed by no more than $10 \%$ from the arithmetic mean.

The flash point was determined in accordance with GOST 4333:2018 using an open crucible temperature measuring device. However, the difference between the test values did not exceed $4{ }^{\circ} \mathrm{C}$.

Mechanical impurities were determined according to GOST $6370-83$ by the formula:

$$
X=\frac{\left(m_{1}-m_{2}\right)}{m_{3}},
$$

where $\mathrm{m}_{1}-$ mass of the filter with mechanical impurities, $\mathrm{g} ; \mathrm{m}_{2}-$ mass of the filter, $\mathrm{g} ; \mathrm{m}_{3}-$ sample mass, g.

\section{Discussion of experimental data}

In a number of works [6-10, 13, 14], it is noted that the purification/regeneration of used oils by synthetic or natural sorbents is an efficient and technologically simple method. In order to investigate the possibility of regeneration of used industrial oils, we have used the used mixed sorbent $(\mathrm{AC}+\mathrm{K})$ after the purification of sugar syrup of the production of soft drinks (Panda, Vinnytsia). The composition of this mixed sorbent $(A C+K)$ included natural sorbents Becogur 3500 and Becogur 200 and activated charcoal Decolar A. Becogur 3500 is a rough kieselguhr (diatomaceous earth) of a fixed granulometric composition, which provides the required speed and depth of filtration. Becogur 200 is a kieselguhr with very small granulometric composition and high filtration efficiency. Activated charcoal Decolar A is a highly active sorbent with a specific adsorption surface of $1500-1800 \mathrm{~m}^{2} / \mathrm{g}$, which is widely used in the food industry. In our opinion, such a composition of sorbents with different chemical nature, characterized by different specific adsorption surface, must have provided the necessary depth and quality of purification of industrial oils. At the same time, a prerequisite for the effective use of the investigated sorbents $(\mathrm{AC}+\mathrm{K})$ was their regeneration, carried out under the conditions shown in Table 1 .

Table 1

\begin{tabular}{|c|c|c|c|c|c|c|c|c|c|}
\hline \multirow{3}{*}{$\begin{array}{l}\text { Example } \\
\text { number }\end{array}$} & \multirow{3}{*}{$\begin{array}{l}\text { Mixed sorbent } \\
\qquad(\mathrm{AC}+\mathrm{K})\end{array}$} & \multicolumn{7}{|c|}{ Conditions of regeneration } & \multirow{3}{*}{$\begin{array}{c}\text { Iodine } \\
\text { sorption } \\
\text { capacity, } \\
\text { relative \% }\end{array}$} \\
\hline & & \multicolumn{3}{|c|}{$\begin{array}{c}\text { Treatment of } \mathrm{NaOH} \text { solution, } \\
\%\end{array}$} & \multicolumn{4}{|c|}{ Treatment of $\mathrm{HCl}$ solution, \% } & \\
\hline & & 0,0 & 0,5 & 1,0 & 0,0 & 1,0 & 2,0 & 4,0 & \\
\hline 1 & regenerated & & + & & + & & & & 90,3 \\
\hline 2 & regenerated & & & + & + & & & & 96,7 \\
\hline 3 & regenerated & + & & & & + & & & 83,8 \\
\hline 4 & regenerated & + & & & & & + & & 84,0 \\
\hline 5 & regenerated & + & & & & & & + & 87,0 \\
\hline 6 & regenerated & & & + & & & & + & 100,0 \\
\hline 7 & unregenerated & + & & & + & & & & 58,0 \\
\hline 8 & opening & + & & & + & & & & 100,0 \\
\hline
\end{tabular}

The results of regeneration of the sorbent mixture

* As $100 \%$ was accepted sorption capacity of a mixture of activated charcoal and kieselguhr prior to its use in the process (initial mixed sorbent).

Given in Table 1 data show that the regeneration of the sorbent mixture (examples 1,2 ) only with a solution of $\mathrm{NaOH}$ allows to increase their sorption capacity compared to the unregenerated mixture of sorbents (example 7) by 32,3-38,7\%. The regeneration of mixed sorbents (examples 3-5) only with $\mathrm{HCl}$ solution is less 
efficient and the sorption capacity is increased by only $25.8-29.0 \%$. The best result was obtained by jointly treating the mixture of sorbents with $\mathrm{NaOH}$ and $\mathrm{HCl}$ solutions (example 6), while the sorption capacity increased by $42 \%$ and reached the value of the sorbent capacity $(\mathrm{AC}+\mathrm{K})$, which they had before their technological use in the purification of sugar syrup. Thus, the data presented (examples 1-8) indicate the possibility of effective regeneration of a mixture of activated charcoal and kieselguhr and their re-use for the purification/regeneration of used industrial oils.

In the study of purification of industrial used oil by adsorption method we have established the following optimal technological parameters of its regeneration: stirring speed is $1000-1200 \mathrm{rpm}$; ratio is $(\mathrm{AC}+\mathrm{K}):(\mathrm{UO})=$ 1:10-20; temperature of the adsorption process is $20-25^{\circ} \mathrm{C}$; time of the adsorption is $30-60 \mathrm{~min}$.

The adsorbent was separated from the purified industrial oil by vacuum filtration on a Schott filter, and the efficiency of purification/regeneration of industrial oil was determined by determining its basic physicochemical characteristics according to regulatory documents. The basic physico-chemical characteristics of the studied industrial oils obtained by the above methods are given in Table. 2.

Table 2

\section{Physico-chemical characteristics of industrial oils}

\begin{tabular}{|c|c|c|c|c|c|c|c|c|}
\hline \multirow{3}{*}{ № } & \multirow{3}{*}{ Characteristic } & \multirow{3}{*}{$\begin{array}{c}\text { Oil } \\
\text { I-40A SN } \\
300^{*}\end{array}$} & \multirow{3}{*}{$\begin{array}{l}\text { Used oil } \\
\text { (UO) } \\
\text { I-40A }\end{array}$} & \multicolumn{3}{|c|}{ Regenerated oil } & \multicolumn{2}{|c|}{$\begin{array}{l}\text { Conditions of } \\
\text { regeneration }\end{array}$} \\
\hline & & & & \multicolumn{3}{|c|}{ Mass ratio $(\mathrm{AC}+\mathrm{K}):(\mathrm{UO})$} & \multirow{2}{*}{$\begin{array}{c}\text { Temper } \\
\text { ature, } \\
{ }^{\circ} \mathrm{C}\end{array}$} & \multirow{2}{*}{$\begin{array}{l}\text { Time, } \\
\min \end{array}$} \\
\hline & & & & $1: 10$ & $1: 15$ & $1: 20$ & & \\
\hline 1 & $\begin{array}{l}\text { Kinematic viscosity } \\
\text { at } 40{ }^{\circ} \mathrm{C}, \mathrm{mm}^{2} / \mathrm{sec}\end{array}$ & $61-75$ & 70 & 73 & 72 & 71 & $20-25$ & $30-60$ \\
\hline 2 & Water content, \% wt. & traces & 0,15 & traces & traces & 0,05 & $20-25$ & $30-60$ \\
\hline 3 & $\begin{array}{l}\text { Acid value, mg } \\
\mathrm{KOH} / \mathrm{g},\end{array}$ & 0,05 & 0,81 & 0,09 & 0,22 & 0,37 & $20-25$ & $30-60$ \\
\hline 4 & Optical density, $\mathrm{D}_{470}$ & 0,082 & 0,362 & 0,093 & 0,210 & 0,298 & $20-25$ & $30-60$ \\
\hline 5 & $\begin{array}{l}\text { Flash point in open } \\
\text { crucible, }{ }^{\circ} \mathrm{C}\end{array}$ & 220 & 210 & 220 & 218 & 212 & $20-25$ & $30-60$ \\
\hline 6 & $\begin{array}{c}\text { Mechanical } \\
\text { impurities, \% wt. }\end{array}$ & none & 0,23 & none & none & none & $20-25$ & $30-60$ \\
\hline 7 & Density, g/ml & 0,886 & 0,900 & 0,890 & 0,895 & 0,897 & $20-25$ & $30-60$ \\
\hline
\end{tabular}

* Manufacturer Delfin Industry Ukraine Ltd., Chernihiv region, GOST 29799-88.

At the same time adsorption purification of $\mathrm{UO}$ with mass ratio $(\mathrm{AC}+\mathrm{K}):(\mathrm{UO})=1: 20$ improves the physico-chemical characteristics of I-40A oil: decreases acid value by 1.7 times, water content by 3.0 times, optical density by 1.2 times; the kinematic viscosity and flash point of the product are also satisfactory, however, the total values of purified UO are lower than those which has the pure industrial oil I-40A SN 300. In the case of adsorption purification using a mass ratio $(\mathrm{AC}+\mathrm{K}):(\mathrm{UO})=1: 10$ the obtained physico-chemical characteristics of the regenerated industrial oil are significantly higher than those obtained using the ratio $(\mathrm{AC}+$ $\mathrm{K}):(\mathrm{UO})=1: 20$. In this case, the recovered oil is only in two respects: acid number and opt its density is inferior to the "pure" oil I-40A SN 300. The intermediate values of the physico-chemical characteristics of the recovered oils were obtained using the mass ratio $(\mathrm{AC}+\mathrm{K}):(\mathrm{UO})=1: 15$. However, despite the difference between the obtained physico-chemical characteristics of the regenerated industrial oil I-40A, which are given in Table 2, it is crucial that the adsorption treatment of used industrial oils using mixed sorbents $(\mathrm{AC}+\mathrm{K})$ is effective and technological. This is evidenced by the closeness of the main characteristic of industrial oils, namely kinematic viscosity. For I-40A SN 300 oil it is $61-75 \mathrm{~mm}^{2} / \mathrm{sec}$, and for our industrial oil $-73 \mathrm{~mm} / \mathrm{sec}$.

Thus, our studies indicate that regenerated industrial oils can be reused for their intended purpose or act as a base for the development of, for example, high-temperature and high-pressure special-purpose lubricants [15]. 


\section{Conclusions}

It has been studied the possibility of adsorption purification/regeneration of used industrial oils using mixed sorbents consisting of activated charcoal Decolar A and kieselguhr of various modifications Becogur 3500 and Becogur 200, taken in a mass ratio of 4: 6 .

The optimum technological parameters for the purification/regeneration of used industrial oil have been experimentally established. It has been shown that regenerated industrial oil can be reused for its intended purpose or applied as a base for other oils or lubricants.

\section{References}

1. Червінський Т. І., Гринишин О. Б., Корчак Б. О. Регенерація відпрацьованих моторних олив у присутності карбаміду // Вісник Національного університету «Львівська політехніка». - 2015. - № 812. С. $158-163$.

2. Майборода C. Э. Целевые продукты переработки (утилизации) отработанных масел производителем смазочных материалов в Российской Федерации // Экологический вестник России. 2013. - № 11. - С. 22-26.

3.Григоров А. Б., Наглюк И. С. Техническое обслуживание транспортных машин и регенерация отработанных масел // Вісник СевНТУ: збірник наукових праць. Серія: Машинобудування та транспорт. - 2013. - Вип. 142. - С. 44-47.

4.Курмаев Р. Н., Глушанкова И. С., Вайсман Я. И. Выбор и обоснование метода утилизации отработанных масел на крупных промышленных предприятиях // Транспорт. Транспортные сооружения. Экология. - 2016. - № 1. - С. 38-51.

5.Гриценко В.О., Орлов Н.С. Применение микрофильтрации для регенерации отработанных моторных масел // ВИНИТИ. Серия. Критические технологии. Мембраны. - 2002. - № 16. - С. 10-16.

6.Сахибов Н. Б. Физико-химические основы регенерации отработанных индустриальных масел природными сорбентами: автореф. дис. канд. техн. наук, Институт химии им. В. И. Никитина АН Республики Таджикистан, Душанбе, 2012.

7.Филоненко В. Ю. Регенерация отработанных технических масел с использованием модифицированных природных глинистых сорбентов: автореф. дис. канд. техн. наук, Липецкий государственный технический университет, РФ, М., 2004.

8.Заматырина В. А. Метод очистки сточных вод от тяжелых металлов и нефтепродуктов с использованием модифицированного органобентонита: автореф. дис. канд. техн. наук, ФГБОУ ВПО «Саратовский государственный технический университет имени Гагарина Ю. А.», РФ, Саратов, 2015.

9.Коваль Е. О., Богомолов М. С., Майер Э. А., Бондалетов В. Г. Адсорбционная очистка отработанного трансформаторного масла с использованием промышленных монтмориллонитсодержащих сорбентов // Изв. Томского политехнического ун-та. - 2007. - Т. 310, № 3. C. 86-89.

10. Хужакулов А. Ф., Тухтаев Б. Б. Адсорбционная очистка турбинного масла Тп-30 // Молодой ученый. - 2016. - Т. 106, № 2. - С. 252-254.

11. Корчак Б. О., Червінський Т. І., Гринишин О. Б. Термоокисна регенерація відпрацьованих індустріальних олив // Вісник Нац. ун-ту «Львівська політехніка». Серія: Хімія, технологія речовин та їх застосування. - 2016. - № 841. - С. 102-107.

12. Ранский А. П., Худоярова О. С., Гордиенко О. А., Титов Т. С., Крикливый Р. Д. Регенерация смеси сорбентов после очистки оборотных вод производства безалкогольных напитков // Хімія i технологія води. - 2019. - Т. 41, № 5. - С. 537-544.

13. Шашкин П. И., Брай И. В. Регенерация отработанных нефтяных масел, М.: Химия, 1970. - 303

c.

14. Полункін С. В., Зубенко С. О., Корж Г. В. Адсорбційне очищення турбінних олив за допомогою природних сорбентів - бентонітових глин // Вісник НАУ. - 2010. - Т. 42, № 1. - С. $253-257$.

15. Худоярова О. С., Гордієнко О. А., Блажко А. В., Панченко Т. І., Ранський А. П. Десульфуризація промислових водно-лужних розчинів та отримання нових пластичних мастил // Матеріали 3-ї міжнародної науково-практичної конференції «Водопостачання та водовідведення: проектування, будова, експлуатація, моніторинг»/ уклад.: Д. Орачевська, Н. Вронська. - Львів : Видавництво Львівської політехніки, 2019. - С. 138-139. 
Худоярова О. С., Гордіснко О. А., Тітов Т. С., Ранський А. П., Диха О. В. Адсорбційна регенерація відпрацьованих індустріальних мастил.

Обгрунтована доцільність та досліджена можливість використання попередньо регенерованої суміші сорбентів, що складалась із активованого вугілля та кізельгуру, для регенерації відпрацьованих індустріальних олив. Встановлено основні фізико-хімічні властивості регенерованої індустріальної оливи, що вказує на ефективність і технологічність дослідженого методу очищення та можливість повторного ії̈ використання за цільовим призначенням.

Ключові слова: відпрацьовані індустріальні оливи, адсорбція, активоване вугілля, кізельгур, регенерація. 